\title{
The Welfare Test: Determining the Indeterminate
}

\author{
Elaine Sutherland, University of Stirling, Stirling UK and Lewis and Clark Law School, \\ Portland, OR
}

This is an Author's Accepted Manuscript of an article published by Edinburgh University Press in Edinburgh Law Review . The Version of Record will be available online at: http://www.euppublishing.com/loi/elr

\section{A. INTRODUCTION}

Many parting or never-together parents reach agreement on the future arrangements for the care of their child, sometimes with the help of a third party, like a mediator. When they cannot agree, disputes may be particularly acrimonious and intractable, with $N J D B v J E G^{1}$ providing a graphic illustration of disputes of this kind at their worst. How the law frames the criteria for decisionmaking in disputed cases is important, not only for those who litigate, but also by providing context for those "bargaining in the shadow of the law".2

In reaching decisions about parental responsibilities and parental rights, the Scottish courts are directed, in terms of the Children (Scotland) Act 1995 (hereafter the "1995 Act"), to accord paramountcy to the welfare of the child concerned; to respect the child's participation rights; and to refrain from making any non-beneficial order. ${ }^{3}$ In this, the law complies with and sometimes exceeds the requirements of the United Nations Convention on the Rights of the Child (CRC). ${ }^{4}$ Taking account of any views the child wishes to express is a critical part of the

\footnotetext{
${ }^{1}$ [2012] UKSC 21, 2012 SC (UKSC) 293. The case involved a dispute between unmarried parents over whether the father should have contact with their 10 year-old son. The proof in the sheriff court lasted for some 52 days, taking over a year to complete, before the case moved on to the Inner House and then to the Supreme Court.

${ }^{2}$ The reference here is, of course, to the seminal article on alternative dispute resolution: Robert H Mnookin and Lewis Kornhauser, "Bargaining in the Shadow of the Law: The Case of Divorce" 88 Yale L.J 950 (1979).

3 The 1995 Act, section 11(7).

${ }^{4}$ Article 3 requires that the child's best interests be a primary consideration in all decisions affecting the child, while article 12 recognises the place of the child's views in the decisionmaking process. Article 5 acknowledges the child's evolving capacity and the central role of
} 
process and is discussed elsewhere. ${ }^{5}$ This note focusses on the welfare test used by courts to prioritise the child's welfare, arguing for clarification of the test by devising a welfare checklist. In passing, it offers an explanation of the apparent reluctance to do so.

The welfare test has something of a Janus-like quality, combining the virtue of flexibility with the vice of vagueness. ${ }^{6}$ Its flexibility enables courts to make individualised assessments of what will best serve a particular child, bearing in mind that children live in infinitely varied situations. Flexibility, however, is not cost-free and its price is uncertainty. Often known as "the best interests test" in other jurisdictions and internationally, the welfare test has received its share of criticism over the years, with Robert Mnookin famously describing it as "vague and indeterminate". ${ }^{7}$ Many jurisdictions have sought to curtail this indeterminacy - and the judicial discretion that accompanies it - by devising statutory "welfare checklists", listing the factors that are relevant in assessing welfare. That approach has found support from the United Nations Committee on the Rights of the Child (UNCRC) and it has offered extensive guidance on how such lists should be framed and operate. ${ }^{8}$

\section{B. FROM UNADORNED WELFARE TEST TO PARTIAL CHECKLIST}

The welfare test, as applied to intra-family disputes, is found in Part I of the 1995 Act. Very much a product of the recommendations of the Scottish Law Commission, the statute directs courts to regard "the welfare of the child concerned as its paramount consideration". 9 The original version of the Act said nothing further about welfare. That was no accident, since the Commission had rejected a welfare checklist, quite explicitly, on the basis that it would be

family members in the upbringing of children.

${ }^{5}$ Elaine E Sutherland, "Listening to the Voice of the Child: The Evolution of Participation Rights" (2013) 26 NZLR 335 and Elaine E Sutherland, "Listening to the Child's Voice in the Family Setting: From Aspiration to Reality" (2014) 26(2) CFLQ 152.

${ }^{6}$ That simile was first used by the present author in an in-depth analysis of the drafting and impact of article 3 of the CRC: Elaine E Sutherland, "Article 3 of the UN Convention on the Rights of the Child: The Challenges of Vagueness and Priorities" in Elaine E Sutherland and Lesley-Anne Barnes Macfarlane (eds), Implementing Article 3 of the United Nations Convention on the Rights of the Child: Best Interests, Welfare and Well-Being (2016) 21 at 36.

${ }^{7}$ Robert H Mnookin, "Child Custody Adjudication: Judicial Functions in the Face of Indeterminacy" (1976) 39 LCR 226 at 229.

${ }^{8}$ General Comment No. 14 on the right of the child to have his or her best interests taken as a primary consideration (art 3, para. 1), CRC/C/GC/14 (2013).

${ }^{9} 1995$ Act section 11(7)(a). 
necessarily incomplete, might divert attention from other factors which ought to be considered and risked judges taking a mechanical approach to decision-making in order to minimise the prospect of a successful appeal. ${ }^{10}$ Academics produced unofficial welfare checklists, ${ }^{11}$ based on the factors courts have considered significant, but the statutory welfare test remained unadorned.

In 2006, in response to concern over two specific issues, the impact of domestic abuse on children and the obstruction of contact by the child's resident parent, the 1995 Act was amended. In assessing welfare, courts are now required to have regard "in particular" to the need to protect the child from domestic abuse. ${ }^{12}$ When they are contemplating making an order that would require adults to co-operate with each other, courts are directed to "consider whether it would be appropriate to make the order" ${ }^{13}$ In effect, there is now a partial welfare checklist that highlights two important factors, but makes no mention of other considerations that might be of equal or greater relevance in a given case - one of the very dangers the Commission had sought to avoid. Arguably, this half-way house is the least satisfactory option: having a partial checklist is worse than having none at all.

\section{REINING IN THE WELFARE TEST}

The vagueness and indeterminacy of the welfare test have long been the subject of academic lament, not least because they open the door to, almost unbridled, judicial discretion, allowing "gender biases and subjective value judgments to replace objective considerations" 14 and enabling "capricious decision-making". ${ }^{15}$ As a result, the values of the dominant political, cultural or religious group may be imposed on those who do not fit the standard pattern, leading

${ }^{10}$ Scottish Law Commission Report on Family Law (Scot Law Com No 135, 1992) paras 5.205.23

${ }^{11}$ See, for example, Elaine E Sutherland, Child and Family Law, 2nd edn (2008) paras 6-169-6215.

121995 Act section 11(7A) and (7B), added by the Family Law (Scotland) Act 2006 (hereafter the "2006 Act").

131995 Act section 11(7D), added by the 2006 Act.

${ }^{14}$ Robert A Warshak, “The Approximation Rule, Child Development Research, and Children's Best Interests After Divorce", (2007) 1(2) Child Development Perspectives 119 at 120.

${ }^{15}$ Stephen Parker, "The Best Interests of the Child - Principles and Problems" in Philip Alston (ed), The Best Interests of the Child (1994) 3. See also, Helen Reece, "The paramountcy principle: consensus or construct?" (1996) 49 CLP 267 at 273. 
to discrimination against those who do not conform. ${ }^{16}$ Nor are the flaws of an indeterminate best interest test confined to the resulting inequity. Since indeterminacy leads to unpredictability, it is argued, it reduces the incentive for the parties to negotiate a settlement and results in increased resort to litigation. ${ }^{17}$

One antidote to the vagueness of an unadorned welfare or best interests test is to devise a statutory welfare checklist, something supported by numerous academic commentators, ${ }^{18}$ with Robert Warshak making the bold claim that this approach can "minimize the drawbacks of the best-interests standard while retaining its virtues". ${ }^{19}$ Many jurisdictions have taken this path ${ }^{20}$ and, since regulation of family law is the province of the individual states, the United States provides particularly rich pickings in terms of what can be done with welfare checklists. ${ }^{21}$ While both the Uniform Law Commission ${ }^{22}$ and the American Law Institute ${ }^{23}$ have offered model checklists, many states have formulated their own versions and the recent experience in Pennsylvania is instructive. In 2011, rather dated legislative provisions were replaced by a 16-

${ }^{16}$ See, for example, Lynne Marie Kohm, "Tracing the Foundations of the Best Interests of the Child Standard in American Jurisprudence" (2008) 10 JL \& Fam Stud 337, 374 (impact on religious parents); Barbara Ann Atwood, Children, Tribes, and States: Adoption and Custody Conflicts over American Children" (2010) 8 (impact on Native American parents); and Reece at 291 (impact on gay and lesbian parents).

${ }^{17}$ Mnookin at 262; Reece at 273; Linda Jellum, "Parents Know Best: Revising our approach to parental custody agreements" (2004) 60 Ohio St LJ 615 at 630.

${ }_{18}$ Mnookin at 226, Barbara Bennett Woodhouse, "Child Custody in the Age of Children's Rights" (1999) 33 FLQ 815 at 829; Mitchell Woolf, "Coming of age? The principle of 'the best interests of the child"' (2003) 2 EHRLR 205 at 208.

${ }^{19}$ Warshak, 120.

${ }^{20}$ See, for example, the Family Law Act 1975 section 60CC (Australia), the Children Act 1989, section 1(3) (England and Wales), Children's Act 2005 section 7(1) (South Africa) and the Care of Children Act 2004 sections 4 and 5 (New Zealand).

${ }^{21}$ For a discussion of their content, see, Linda D Elrod, Child Custody Practice and Procedure (2017) ch 4.

${ }^{22}$ Uniform Marriage and Divorce Act $1970 \S 402$.

23 The American Law Institute, Principles of the Law of Family Dissolution: Analysis and Recommendations (2002). While $\S 2.08$ introduced the controversial "approximation rule", basing parenting time on past discharge of parenting functions, the Comment on $\S 2.02$ makes clear that the goal of the Principles is "to clarify and define the best-interests standard rather than to eliminate it" and a number of checklists are offered for decision-making in different contexts. 
point statutory welfare checklist ${ }^{24}$ and the verdict from judges and attorneys has been favourable. ${ }^{25}$

Welfare checklists should not, however, be regarded as a panacea. It will be remembered that the strength of the welfare test lies in is its flexibility, allowing courts to engage in the individualised decision-making to which every child is entitled. If the checklist is incomplete, a danger the Scottish Law Commission saw as inevitable, then factors that are relevant to the particular child might be left out of account. Most statutes seek to avoid this problem by requiring that account be taken of "any other relevant circumstance" or the like.

Another limitation of checklists is that they do not normally indicate the relative weight to be accorded to the different factors but, then, a strict hierarchy would detract from individualised decision-making. There is also the possibility that different factors on the checklist will point to contradictory conclusions. All of that leaves considerable scope for judicial discretion, something noted by John Eekelaar many years ago, when he observed, "a judge can consider almost any factor which could possibly have a bearing on a child's welfare and assign to it whatever weight he or she chooses." 26 That may be so, but a degree of judicial discretion is inevitable in individualised decision-making.

There is a further danger, stemming not from welfare checklists themselves but, rather, from the process of drafting them. There is the possibility that a particularly vocal lobbying group will advocate for a particular course of action, drowning out other voices and skewing the way welfare decisions are taken. That was the experience in Australia when those supporting "shared parenting" prevailed and the existing legislation was amended, in 2006, giving equal weight to the benefit of the child having a "meaningful relationship" with both parents and the need to protect the child from exposure to domestic abuse. ${ }^{27}$ It became apparent that this approach compromised protection against domestic abuse ${ }^{28}$ and further amending legislation was passed. ${ }^{29}$

2423 Pa. C.S.A. $§ 5328$.

${ }^{25}$ Christian Badali, "Child Custody Factors Have Brought Clarity To Family Law" The Legal Intelligencer, December 30, 2014.

${ }^{26}$ John Eekelaar, Regulating Divorce (1991) 125.

${ }^{27}$ Family Law Amendment (Shared Parental Responsibility) Act 2006.

${ }^{28}$ Richard Chisholm, Family Courts Violence Review (2009) and Social Policy Research Centre, Shared Care Parenting Arrangements since the 2006 Family Law Reforms (2010).

${ }^{29}$ Family Law Legislation Amendment (Family Violence and Other Measures) Act 2011. See, D 
Kelly Weisberg, “In Harm's Way: The Evolving Role of Domestic Violence in the Best Interests Analysis" in Sutherland and Barnes Macfarlane, Implementing Article 3 at 258-262. 


\section{GUIDANCE FROM THE UNCRC}

In General Comment 14, ${ }^{30}$ the United Nations Committee on the Rights of the Child (UNCRC) offered extensive guidance on how to implement the requirements of article 3(1) of the CRC, according primacy to the child's best interests in all decisions affecting the child. ${ }^{31}$ The Committee was well aware of the criticisms levelled at welfare checklists and the following is its elegant solution:

The Committee considers it useful to draw up a non-exhaustive and non-hierarchical list of elements that could be included in a best-interests assessment by any decision-maker having to determine a child's best interests. The non-exhaustive nature of the elements in the list implies that it is possible to go beyond those and consider other factors relevant in the specific circumstances of the individual child or group of children. All the elements of the list must be taken into consideration and balanced in light of each situation. The list should provide concrete guidance, yet flexibility. ${ }^{32}$

The UNCRC saw no need to strive for completeness since a non-exhaustive, non-hierarchical list of elements provides the flexibility that will ensure individualised decision-making. It went on to provide full discussion, not only of the elements it saw as central, ${ }^{33}$ but also of how the assessment and determination should be carried out, requiring evaluation to be by means of a "transparent and objective formal process" 34 that incorporates "child-friendly procedural safeguards". ${ }^{35}$

\section{E. THE ELEPHANT IN THE ROOM}

\footnotetext{
${ }^{30}$ General Comment No. 14.

${ }^{31}$ General Comments are simply non-binding guidance to states parties to the Convention: International Law Association: Committee on International Human Rights Law and Practice, Final Report on the Impact of Findings of the United Nations Human Rights Treaty Bodies (2004) paras 16 and 18.

${ }^{32}$ General Comment No. 14, para 50.

${ }^{33}$ General Comment No. 14, paras 52-84.

${ }^{34}$ General Comment No 14, para 87.

${ }^{35}$ General Comment No 14, paras 85-99. For recent UK examples of a more child-friendly approach, see, Lesley-Anne Barnes Macfarlane, "Patrick $v$ Patrick and Re a letter to a young person: Judicial letters to children - an unannounced, but not unwelcome, development" in this issue of the Edinburgh Law Review.
} 
No discussion of the welfare of the child would be complete without reference to the sometimeshyphenated term, "wellbeing". It too has been endorsed in the CRC and features, alongside best interests, in article 3, with states parties being required to "ensure the child such protection and care as is necessary for his or her well-being." "36 The fact that the CRC uses the terms "best interests" and "well-being" in such close proximity is, in itself, an indication that the terms mean different things, something wholly consistent with the history of wellbeing and its use to denote an outcome. ${ }^{37}$ Wellbeing has its roots in the social sciences, yet social scientists admit that it is notoriously difficult to define, ${ }^{38}$ which explains why international efforts have focussed instead on developing "performance indicators" as a way to measure progress in improving child wellbeing. ${ }^{39}$

In Scotland, "wellbeing" came to legislative prominence in the Children and Young People (Scotland) Act 2014, which provides that it is to be assessed by "by reference to" the SHANARRI indicators: that is, the extent to which the child would be "safe, healthy, achieving, nurtured, active, respected, responsible and included". ${ }^{40}$ These indicators began life as tools, used primarily by social workers, to summarise the child's needs and to identify and monitor the intended outcomes of any planned intervention. ${ }^{41}$ Undertaking such an assessment is entirely

\footnotetext{
${ }^{36}$ Article 3(2).

${ }^{37}$ See, for example, the Preamble to the Constitution of the World Health Organisation, adopted in 1946, defining health as "a state of complete physical, mental and social well-being and not merely the absence of disease or infirmity".

${ }^{38}$ See, for example, Gaelle Amerijckx and Perrine Claire Humblet "Child Wellbeing: What Does it Mean?" (2014) 28 Children and Society 404, at 405 ("to date, there is no consensus on a definition") and Asher Ben-Arieh, "Social Policy and the Changing Concept of Child Wellbeing: The role of international studies and children as active participants" (2014) 60(4) Zeitschrift Für Padagogik 569, at 151 (referring to well-being as a "conceptually muddy" term).

${ }^{39}$ See, for example, Revised Results Framework for the UNICEF Strategic Plan, 2014-2017, E/ICEF/2016/6/Add.2, listing the indicators developed by UNICEF to measure progress in child protection. They are quantitative and thus, specific, including, inter alia, whether a country has achieved a $10 \%$ reduction in the number of 2 to 14 year-olds who have experienced violent discipline in the home or a $10 \%$ reduction in the number of 15-17 year-old girls who have experienced sexual violence or a $10 \%$ reduction in the number of children in residential care. ${ }^{40}$ Children and Young People (Scotland) Act 2014, section 96(2).

${ }^{41}$ Bob Stradling and Bill Alexander, 'Getting it right for children: promoting effective change' in Malcolm Hill, George Head, Andrew Lockyer, Barbara Reid and Raymond Taylor (eds), Children's Services: Working Together (2012) 67.
} 
appropriate for professionals who are providing services to children and young people. It is not, however, the province of lawyers or courts.

When the 2014 Act was being drafted, it was suggested that the term "wellbeing" should replace "welfare" in all of the legislation dealing with children. The criticism that "welfare" is ambiguous pales into insignificance when one contemplates how a court would determine what will make a child feel "nurtured" or "respected" or "included". Happily, the suggestion for legislative amendment sank without trace. Should it resurface, the distinct history and nature of wellbeing provide ample reason to reject its pervasive - and wholly inappropriate - use.

\section{F. CONCLUSION}

That the welfare or best interests test has much to commend it is evidenced by its widespread use in domestic legislation and adoption in the CRC. Even Mnookin, its arch-critic, observed, "While the indeterminate best-interests standard may not be good, there is no available alternative that is plainly less detrimental." 42

Its indeterminacy is an inevitable corollary of its flexibility, but the former can be curtailed by the use of a welfare checklist. Why, then, is there no such checklist in Scotland? It may be that practitioners find sufficient guidance in the unofficial checklists and that the courts are confident of their own expertise. Others, however, are not so sanguine and numerous individuals, sometimes allied to particular lobbying groups, have submitted petitions to the Scottish parliament seeking amendment of the legislation. ${ }^{43}$ These petitions may provide a clue to the real reason behind the absence of a Scottish welfare checklist.

Devising a welfare checklist would require addressing many difficult questions about what truly serves the welfare of children in all the manifold circumstances in which they find themselves. Should there be a presumption in favour of shared parenting or its troublesome cousin, equal parenting time? Is past abuse of one parent by the other relevant? What should be the response to an intransigent parent who obstructs the child's relationship with the other

\footnotetext{
${ }^{42}$ Mnookin at 282.

${ }^{43}$ See, for example, PE01513: Equal Rights for Unmarried Fathers (lodged 14 April 2014; closed 12 May 2015); PE01528: Child court reform (lodged 3 July 2014; closed 12 May 2015) (advocating a presumption in favour of 50/50 contact for both "fit" parents); PE01570: Parental Rights To Child Contact (lodged 15 July 2015; closed 23 February 2016) (addressing obstruction of contact).
} 
parent? Where (if at all) do other family members, like siblings, step-parents and grandparents, feature? These are matters on which there are strong, sincerely-held and differing views. The recent BRIA Review of the Children (Scotland) Act 1995 raised many of these questions and the reviewers may well have found almost as many shades of opinion as there were respondents. ${ }^{44}$

Any attempt, in Scotland, to devise a welfare checklist would undoubtedly involve robust debate. Experience from other countries tells us that this may not be a pretty sight, with one Canadian scholar referring to "gender wars" and "polemic rhetoric" afflicting the process in a country justifiably renowned for civility. ${ }^{45}$ Yet we should not shy away from testing questions simply because dealing with them is likely to be challenging, contentious and, sometimes, uncomfortable.

It is crucial to remember that the children whose futures are at stake when courts make decisions about parental responsibilities and parental rights did not create the problem. It was the adults in their lives who did that. It now falls to the adult world, in consultation with children and young people, to find a way to resolve disputes equitably and efficiently. Devising a nonexhaustive and non-hierarchical welfare checklist of the kind envisaged by the UNCRC would contribute to that process by providing courts with a tool to assist them in making individualised decisions designed to secure that the child's welfare remains paramount.

Elaine E. Sutherland University of Stirling Law School, Scotland, and Lewis \& Clark Law School, Portland, Oregon

\footnotetext{
${ }^{44}$ At the time of writing, the Business and Regulatory Impact Assessment (BRIA) Review of the Children (Scotland) Act 1995 is ongoing. For full details, see the Scottish Government website at: http://www.gov.scot/Topics/Justice/law/17867/review-of-children-scotland-act-1995/1995Act-review-BRIA-interviews

${ }^{45}$ Nicholas Bala, 'Canada's Controversy over Best Interests and Post-Separation Parenting', in Sutherland and Barnes Macfarlane, Implementing Article 3 at 239.
} 